\title{
JBS EM FOCO: O QUE AS DEMONSTRAÇÕES FINANCEIRAS FALAM?
}

JBS IN FOCUS: WHAT DO THE FINANCIAL STATEMENTS SAY?

Recebido em 25.06.2020 Aprovado em 27.07.2020

Avaliado pelo sistema double blind review

DOI: https://doi.org/10.32888/cge.v8i1.43222

\author{
Nataniele Pereira Dias \\ nataniele_ndp@hotmail.com \\ Sistema de Cooperativismo de Crédito Rural - SICREDI - Dourados/Mato Grosso do Sul, Brasil \\ https://orcid.org/0000-0001-6325-1569
}

Cristiane Mallmann Huppes

cristiane huppes@hotmail.com

Universidade Federal da Grande Dourados - Dourados/Mato Grosso do Sul, Brasil

https://orcid.org/0000-0003-3686-2203

\author{
Antonio Carlos Vaz Lopes \\ antoniolopes@ufgd.edu.br \\ Universidade Federal da Grande Dourados - Dourados/Mato Grosso do Sul, Brasil \\ https://orcid.org/0000-0002-3209-3331
}

\section{Rafael Martins Noriller}

rafael.mnoriller@gmail.com

Universidade Federal da Grande Dourados - Dourados/Mato Grosso do Sul, Brasil

https://orcid.org/0000-0001-9981-4669

\section{Resumo}

O presente estudo analisa os relatórios: Balanço Patrimonial, Demonstração do Resultado do Exercício e Notas Explicativas, da empresa JBS, no período de 2008 a 2017, com intuito de observar o desempenho patrimonial e financeiro. De caráter descritivo, de procedimento documental, os dados foram organizados e calculados os índices em planilhas de Excel. Tendo por base os índices de liquidez, rentabilidade e lucratividade, a empresa obteve resultados com perspectivas crescentes de retornos. A participação de capital de terceiros foi significativa e decisiva no crescimento da empresa, possibilitando a expansão e consolidação mundial.

Palavras-chave: Análise das Demonstrações Contábeis; Indicadores Econômico-financeiros; Mercados; Agronegócios.

\begin{abstract}
This study analyzes the reports: Balance Sheet, Income Statement for the Year and Explanatory Notes, from JBS, from 2008 to 2017, in order to observe the equity and financial performance. Descriptive and documentary, the data were organized and indexes were calculated in Excel spreadsheets. Based on the liquidity, profitability and profitability indexes, the company obtained results with growing prospects for returns. The participation of thirdparty capital was significant and decisive in the company's growth, enabling global expansion and consolidation.

Keywords: Analysis of Financial Statements; Economic and financial indicators; Markets; Agribusiness.
\end{abstract}




\section{Introdução}

O estudo em questão envolve a empresa JBS, uma das 5 maiores empresas brasileiras em faturamento dos últimos 6 anos (VALOR ECONÔMICO, 2019), que está entre as 4 maiores empresas do agronegócio brasileiro, junto com as internacionais Cargil, Bunge e ADM (EXAME, 2019). A JBS foi fundada no ano de 1953, transpondo sua existência de pequeno negócio no interior do país, para ser a maior empresa de processamento de carnes no mundo. Os atuais donos da empresa Wesley e Joesley Batista, fundaram uma holding, que incorpora as empresas JBS, Vigor, Flora empresa de higiene, Eldorado do Brasil (papel e celulose), Canal Rural e o Banco Original (VIANA 2017).

Todos estes empreendimentos estão imersos na economia e são relatados ao mercado por meio de Relatórios Contábeis. Assim, a contabilidade elabora relatórios e informações a seus diversos usuários, facilitando a análise da situação empresarial e a tomada de decisão (BRAGA, 2012). Desde os primórdios da Contabilidade, quando essa se resumia à realização de inventários, o homem "analista" já se preocupava com as variações da riqueza (IUDÍCIBUS, 1998).

Os relatórios contábeis são "a exposição resumida e ordenada dos principais fatos registrados pela contabilidade, em determinado período" (IUDÍCIBUS, 1998, p. 39). Por meio dos relatórios é possível tomar decisões, desde as mais cotidianas como comprar e vender, assim como as estratégicas, de apreciar a responsabilidade e o desempenho da administração, deliberar sobre políticas tributárias e distribuição de lucros (BRAGA, 2012; MARION, 2002).

Ainda, Iudícibus (1998, p. 19) destaca que os Demonstrativos Contábeis são importantes para os investidores. Segundo Braga (2012), as Demonstrações Contábeis fornecem informações para tomada de decisão por parte do usuário em geral, sem atender as necessidades ou finalidades de determinados grupos. Tendo como premissa os aspectos descritos sobre as Demonstrações Contábeis, volta-se à empresa JBS que, além de ser uma empreendedora e gigante brasileira, também se envolveu recentemente em escândalos de corrupção no Brasil, fato este que, chama atenção para um estudo minucioso de seus relatórios públicos.

Sendo assim, o presente estudo tem por objetivo realizar a Análise das Demonstrações Contábeis e dos Indicadores de Desempenho da JBS, no período de 2008 a 2017, com o intuito de observar a evolução, tendências e desempenho patrimonial no período em questão. Tendo como base as Demonstrações Contábeis, o cálculo de índices e a posterior análise, proporcionarão uma visão das principais ocorrências patrimoniais no período proposto.

Este estudo justifica-se por apresentar informações de uma das maiores empresas do agronegócio mundial, podendo auxiliar o processo de tomada de decisão de instituições financeiras e investidores. Em tempo, a pesquisa se justifica por apresentar evidências que complementam os estudos de Marcos et al. (2019) e Kronbauer (2013). Kruger (2009) afirma ser fundamental a transparência das demonstrações contábeis das entidades, para que seja demonstrado o patrimônio da entidade e as suas variações nos períodos transcorridos, gerando então, maior credibilidade e confiança para o estado, sociedade e outrem.

Anteriormente envolvida em corrupção, a empresa fechou Acordo de Leniência em 2017 e está em processo de continuidade, gerando receita e tributos, movimentando a economia, empregando pessoas. Sendo assim, além desta introdução, o estudo compreende o referencial teórico que descreve sobre contabilidade e análise das demonstrações. No terceiro item, são descritos aspectos metodológicos e por fim, os resultados, discussões e conclusão.

\section{Análise de Balanços Horizontal e Vertical}

Assaf Neto (2012) afirma que o processo de análise de balanços inicia com as demonstrações contábeis publicadas. A maneira pela qual os indicadores são analisados, são individuais de quem faz a análise. Dois analistas podem analisar a mesma empresa com as mesmas informações e chegar a conclusões diferentes, utilizando a mesma técnica de análise. Iudícibus (1998, p. 26) defende que a análise de balanço "é como a arte de saber extrair relações 
úteis, para o objetivo econômico que tivermos em mente, dos relatórios contábeis tradicionais e de suas extensões e detalhadamente, se for o caso".

Visando um conhecimento minucioso, a situação atual de planejar o futuro comportamento da empresa, Braga (2012) afirma que a Análise das Demonstrações Contábeis tem por objetivo analisar, observar, compreender e confrontar os elementos patrimoniais e os resultados das operações da entidade. Pela temporalidade proposta no estudo (2008 a 2017), a aplicação das análises horizontal e vertical são as primeiras a serem exploradas.

A análise horizontal possibilita o apontamento de crescimento dos itens das demonstrações, a fim de caracterizar tendências (IUDÍCIBUS, 1998). Braga (2012, p. 134) afirma que: "Por esse método, determina-se a tendência dos valores absolutos ou relativos das diversas grandezas monetárias, apurando-se o percentual de crescimento ou declínio de valores de uma mesma conta ou grupo de contas, entre duas datas e/ou períodos considerados." Ainda, Assaf Neto (2012) escreve que a análise horizontal busca identificar a evolução dos elementos patrimoniais e de resultados, analisando o crescimento e a evolução da empresa ao longo de determinado período.

A análise vertical, é importante para avaliar a estrutura de composição de itens e sua evolução no tempo (IUDÍCIBUS, 1998). Também, permite conhecer a participação relativa de cada elemento patrimonial e de resultados da empresa (ASSAF NETO, 2012). Por fim, Braga (2012, p. 136) escreve que o método "consiste no relacionamento dos valores das contas de cada grupo com montante do respectivo grupo, bem como do montante de cada grupo com o total do ativo ou do passivo e patrimônio líquido quando se tratar de balanço patrimonial." O Quadro 1 apresenta uma síntese do conceito e aplicação das análises horizontal e vertical:

Quadro 1: Conceito e Aplicação de Análise Horizontal e Vertical

\begin{tabular}{|c|l|c|l|}
\hline Análise & \multicolumn{1}{|c|}{ Definição } & \multicolumn{1}{|c|}{ Fórmula } & \multicolumn{1}{|c|}{ Metodologia de Aplicação } \\
\hline Horizontal & $\begin{array}{l}\text { Compara os valores de uma mesma conta } \\
\text { ou grupo de contas, em diferentes } \\
\text { exercícios sociais. É um processo de análise } \\
\text { temporal, por meio de números-índices. }\end{array}$ & $\begin{array}{l}\text { Número-Índice }=\text { Período-base }=\text { primeiro } \\
(\mathrm{Va} / \mathrm{Vb})^{*} 100\end{array}$ & $\begin{array}{l}\text { ano de análise. } \\
\text { 2. Período-base }=\text { o exercício } \\
\text { imediatamente anterior. }\end{array}$ \\
\hline Vertical & $\begin{array}{l}\text { Compara a estrutura de composição de } \\
\text { itens e sua evolução no tempo, calculando } \\
\text { o percentual de cada conta com relação a } \\
\text { um valor -base. }\end{array}$ & $\begin{array}{l}\text { Número-Índice }= \\
(\mathrm{Vc} / \mathrm{Vt})^{*} 100\end{array}$ & $\begin{array}{l}\text { 1.Valor-base = valor total da } \\
\text { conta do período analisado. } \\
\text { 2.Valor-base } \\
\text { vabconta do período analisado }\end{array}$ \\
\hline
\end{tabular}

Fonte: Adaptado de Assaf Neto (2012); Matarazzo (2003).

Legenda:

$\mathrm{Va}$ - Valor Atual

$\mathrm{Vb}-$ Valor Base

Vc - Valor da Conta

$\mathrm{Vt}-$ Valor Total

\section{Indicadores de Liquidez, Desempenho e Rentabilidade}

Além das análises horizontal e vertical, existem índices que sinalizam o desempenho de uma empresa. Com destaque para os indicadores de liquidez, desempenho e rentabilidade (ASSAF NETO, 1991). Para Marion (2002), índices de liquidez são utilizados na avaliação da capacidade de pagamento empresarial.

Ross et al. (2008) afirma que esses índices são uma forma de comparar e investigar os relacionamentos entre as diferentes partes das informações e trabalhando com porcentagens em vez do total em moeda corrente. Para a análise financeira são adotados alguns passos como: examinar a demonstração de fluxo de caixa; calcular e avaliar o retorno sobre o capital investido (EHRHARDT E BRIGHAM 2012). Para fins de esclarecimento, o Quadro 2 fornece informação sobre o que é e para que serve cada indicador e suas respectivas fórmulas. 
Quadro 2: Indicadores de Liquidez, de Rentabilidade, Composição e Prazos.

\begin{tabular}{|c|c|c|}
\hline Nome & Fórmula & Definição \\
\hline $\begin{array}{l}\text { Indicador de } \\
\text { Liquidez Corrente }\end{array}$ & $\frac{\text { Ativo Circulante }}{\text { Passivo Circulante }}$ & $\begin{array}{l}\text { Indica a capacidade de pagamentos a } \\
\text { curto prazo. }\end{array}$ \\
\hline $\begin{array}{l}\text { Indicador de } \\
\text { Liquidez Seca }\end{array}$ & $\frac{\text { Ativo Circulante }- \text { Estoque }}{\text { Passivo Circulante }}$ & $\begin{array}{l}\text { Indica a capacidade de pagamento, sem } \\
\text { precisar vender estoques. }\end{array}$ \\
\hline $\begin{array}{l}\text { Indicador de } \\
\text { Liquidez Geral }\end{array}$ & $\frac{\text { Ativo Circulante }+ \text { Realizável a Longo Prazo }}{\text { Passivo Circulante }+ \text { Passivo não Circulante }}$ & $\begin{array}{l}\text { Indica a capacidade de resolver } \\
\text { compromissos de curto e longo prazo. }\end{array}$ \\
\hline $\begin{array}{c}\text { Indicador de } \\
\text { Rentabilidade do } \\
\text { Ativo }\end{array}$ & $\frac{\text { (Lucro Líquido) }}{\text { Ativo Total }} \times 100$ & $\begin{array}{l}\text { Medida do potencial de geração de } \\
\text { lucro indicando quanto o lucro líquido } \\
\text { remunera o ativo. }\end{array}$ \\
\hline $\begin{array}{l}\text { Indicador de } \\
\text { Rentabilidade do } \\
\text { Patrimônio } \\
\text { Liquido }\end{array}$ & $\begin{array}{l}\text { Lucro Líquido } \\
\text { Patrimônio Líquido X } 100 \\
\text { (valor médio) }\end{array}$ & $\begin{array}{l}\text { Quanto a empresa obteve de lucro para } \\
\text { certa quantidade investida. }\end{array}$ \\
\hline $\begin{array}{l}\text { Indicador de } \\
\text { Participação de } \\
\text { Capitais de } \\
\text { Terceiros }\end{array}$ & $\frac{\text { Capitais de Terceiros }}{\text { Patrimônio liquido }}$ & $\begin{array}{l}\text { Mede a estrutura de obrigações e } \\
\text { disponibilidade de capital próprio para } \\
\text { pagar dívidas. }\end{array}$ \\
\hline $\begin{array}{l}\text { Indicador de } \\
\text { Composição do } \\
\text { Endividamento }\end{array}$ & $\frac{\text { Passivo Circulante }}{\text { Capital de Terceiros }}$ & $\begin{array}{l}\text { Demonstra o quanto de obrigações a } \\
\text { curto prazo, para cada } \mathrm{R} \$ 1,00 \text { de } \\
\text { obrigações totais. }\end{array}$ \\
\hline $\begin{array}{l}\text { Indicador de } \\
\text { Capital Próprio }\end{array}$ & $\frac{\text { Ativo não Circulante }}{\text { Patrimônio líquido }} \times 100$ & $\begin{array}{l}\text { Indica a extensão em que o patrimônio } \\
\text { líquido se encontra imobilizado em } \\
\text { ativos. }\end{array}$ \\
\hline $\begin{array}{l}\text { Indicador de } \\
\text { Prazo Médio de } \\
\text { Recebimento } \\
\end{array}$ & $\frac{\text { Duplicatas a Receber X } 360}{\text { Receita Operacional Bruta }}$ & $\begin{array}{l}\text { Indica quando tempo, em média, a } \\
\text { empresa demora a receber suas vendas } \\
\text { diárias. }\end{array}$ \\
\hline $\begin{array}{l}\text { Indicador de } \\
\text { Prazo Médio de } \\
\text { Pagamento }\end{array}$ & $\begin{array}{c}\text { Duplicatas a Pagar } \\
\text { Compras Brutas de Mercadorias e Serviços }\end{array}$ & $\begin{array}{l}\text { Indica em quanto tempo a empresa } \\
\text { consegue pagar seus fornecedores. }\end{array}$ \\
\hline $\begin{array}{l}\text { Indicador de Giro } \\
\text { do Estoque }\end{array}$ & $\frac{\text { Custo dos Pordutos Vendidos }}{\text { Estoque }}$ & $\begin{array}{l}\text { Indica a velocidade com que o estoque } \\
\text { se transforma em produto vendido. }\end{array}$ \\
\hline
\end{tabular}

Fonte: Adaptado de Marion (2002), Assaf Neto (1991), Matarazzo (2003), Iudícibus (1998).

$\mathrm{Na}$ fórmula do Indicador de Rentabilidade do Ativo, há autores que observam a utilização do valor médio do Total do Ativo. Este estudo toma como base de análise o valor do Ativo Total no final do período.

\section{Aspectos Metodológicos}

Ao definir os aspectos metodológicos desta pesquisa, inicialmente há características de estudo exploratório, pois seu desenvolvimento inicial ocorre mediante a premissa de proporcionar uma visão geral acerca de determinado fato, ou seja, uma análise temporal (2008 a 2017, contemplando o período de convergência às FULL IFRS) das demonstrações contábeis da empresa JBS, por meio análises vertical e horizontal das Demonstrações Contábeis, e de índices. Quanto aos resultados dos achados, a característica é de pesquisa descritiva, ou seja, observa, analisa e interpreta, sem a interferência nos fatos (GERHARDT E SILVEIRA, 2009; RAUPP E BEUREN, 2006).

Quanto aos procedimentos, possui uma das características de estudo de caso, ou seja, estudo concentrado em um único caso (YIN, 2005), que é a empresa JBS, bem como documental, pois se baseia em materiais que ainda não receberam um tratamento analítico. As Demonstrações Contábeis foram obtidas nos sites da Comissão de Valores Mobiliários (CVM) e da JBS, no período de junho a julho do ano de 2018, cujos dados foram tabulados em planilhas do Excel, possibilitando os cálculos de análises vertical e horizontal, bem como, calculadas as fórmulas descritas no Quadro 2. 
Quanto a abordagem do problema, são analisadas demonstrações contábeis, que compreendem conceitos contábeis e significação em números (coleta de dados e tratamento dos dados), o que pode caracterizar aspectos quantitativos. Porém, não haverá a aplicação de instrumentos estatísticos e intenção de se fazer inferências. Sendo assim, a classificação se aproxima fortemente de procedimento qualitativo, descrevendo e analisando os resultados advindos das técnicas de análise de balanço (RAUPP E BEUREN, 2006).

O objeto se refere a um grupo empresarial conhecido como Grupo JBS. O início das atividades ocorreu em um pequeno açougue na cidade de Anápolis/GO, no ano de 1953, por José Batista Sobrinho, mais conhecido como Seu Zé Mineiro. A Casa de Carnes Mineira, que representa a cultura e os valores da companhia, em 1957 se tornou um dos primeiros fornecedores de carne bovina para os canteiros de obra que futuramente deram origem a nova capital federal, Brasília - DF. Desta casa de carnes, formou-se a primeira unidade frigorifica, dando origem ao nome Friboi (JBS, 2017).

Ao longo de seu desenvolvimento, em 2004 com suas operações já em nível nacional, fundou-se a Sede da JBS na cidade de São Paulo - SP. Em 2005 deu seu primeiro passo rumo à internacionalização da empresa com a aquisição da SWIFT na Argentina. Atualmente a JBS é controlada pela holding J\&F e atua no mercado com as marcas Seara, Friboi, Massa Leve, Swift e Doriana (JBS, 2017).

A seguir, o Quadro 3 apresenta uma linha do tempo da empresa JBS e sua controladora J\&F:

Quadro 3: Linha do Tempo da J\&F.

\begin{tabular}{|c|c|}
\hline Período & Acontecimento \\
\hline 1953 & $\begin{array}{l}\text { José Batista Sobrinho inicia as operações da JBS em uma pequena casa de carnes, na cidade de Anápolis, } \\
\text { Goiás. }\end{array}$ \\
\hline 1968 & Aquisição da primeira planta de abate de gado em Planaltina (DF). \\
\hline 1970 & $\begin{array}{l}\text { A JBS adquire uma planta de abate em Luziânia (GO) e sua capacidade salta para } 500 \text { cabeças de gado } \\
\text { por dia. }\end{array}$ \\
\hline 1980 & Início das operações da Flora, empresa de higiene e limpeza. \\
\hline 1997 & Aquisição das operações de carne bovina da Sadia pela JBS \\
\hline 2005 & $\begin{array}{l}\text { JBS inicia seu processo de internacionalização com a aquisição da Switf Armour S.A., maior produtora e } \\
\text { exportador de carne bovina na Argentina. }\end{array}$ \\
\hline \multirow{7}{*}{2007} & $\begin{array}{l}\text { JBS é a primeira empresa de processamento de carne bovina a abrir capital na Bolsa de Valores com o } \\
\text { maior IPO até então. }\end{array}$ \\
\hline & $\begin{array}{l}\text { Aquisição da Swift Foods Company, que passa a se chamar JBS USA, marcando o início das operações na } \\
\text { América do Norte. }\end{array}$ \\
\hline & JBS compra a empresa australiana Tasman Group, consolidando sua liderança mundial no setor de carnes. \\
\hline & Criação do Banco JBS, embrião do que hoje é o Banco Original. \\
\hline & $\begin{array}{l}\text { JBS adquire a americana Pilgrim's Pride Corporation, que atua na criação, abate, processamento e } \\
\text { comercialização de carnes de frango. }\end{array}$ \\
\hline & JBS incorpora processamento de carne da companhia Bertin. \\
\hline & Criação do Instituto Germinare. \\
\hline \multirow{2}{*}{2010} & Inauguração da Escola Germinare, iniciativa do Instituto Germinare. \\
\hline & Fundação da Eldorado Brasil e início da construção da planta de celulose. \\
\hline \multirow{2}{*}{2011} & Criação do Banco Original. \\
\hline & Flora expande seu portfólio, incorporando as marcas, OX, Francis, Neutrox, Matinset e Assim. \\
\hline \multirow{2}{*}{2012} & Início das operações da Eldorado Brasil. \\
\hline & Spin-Off da Vigor, tornando-se uma empresa independente da JBS. \\
\hline
\end{tabular}

Continua. 
Continuação.

\begin{tabular}{|c|c|}
\hline Período & Acontecimento \\
\hline \multirow[b]{2}{*}{2013} & Aquisição da Itambé pela Vigor e aquisição do Canal Rural pela J\&F. \\
\hline & $\begin{array}{l}\text { Aquisição da Seara pela JBS e criação da JBS Foods, expandindo sua atuação em frango, suínos e } \\
\text { processados. }\end{array}$ \\
\hline 2014 & $\begin{array}{l}\text { Líder em proteína animal, JBS torna-se a segunda maior empresa de alimentos do mundo e o maior } \\
\text { grupo privado do Brasil. }\end{array}$ \\
\hline \multirow{3}{*}{2015} & JBS realiza uma série de aquisições estratégicas: Cargill Pork nos Estados Unidos e Moy Park na Europa. \\
\hline & Eldorado registra as maiores margens operacionais do setor e seu primeiro lucro. \\
\hline & $\begin{array}{l}\text { J\&F adquire o controle acionário da Alpargatas S.A em uma das mais importantes transações do setor } \\
\text { de moda, vestuário e calçados do Brasil. }\end{array}$ \\
\hline
\end{tabular}

Fonte: Adaptado de J\&F (2018).

Maior processadora de proteína animal do mundo, a JBS atua em cinco continentes nos segmentos de carne bovina, suína, aves e ovinos, além de couro, colágeno, embalagens metálicas, biodiesel e transportes. Seu faturamento é expressivo, que a coloca entre as maiores empresas do país e é dona de marcas internacionalmente reconhecidas, como Swift, Pilgrim's, Friboi, Seara e Frangosul (VAZ, 2017).

\section{Resultados}

Primeiramente, são apresentados os resultados relativos a Análise Horizontal e Vertical das Demonstrações: Balanço Patrimonial e Demonstração do Resultado do Exercício. Para estes cálculos, optou-se por apresentar os resultados tendo como base o período anterior, considerando que apresentam maior oscilação e percepção das mudanças ocorridas. Posteriormente, são apresentados os resultados para a Análise de Indicadores de Liquidez, de Rentabilidade, de Endividamento e Prazos Médios.

\section{Análise Horizontal}

Para demonstrar e avaliar a evolução dos elementos do Grupo Ativo do balanço patrimonial da empresa JBS, analisa-se a Figura 1 tendo como base o ano de 2008.

Figura 1: Balanço Patrimonial Ativo - Período-base 2008

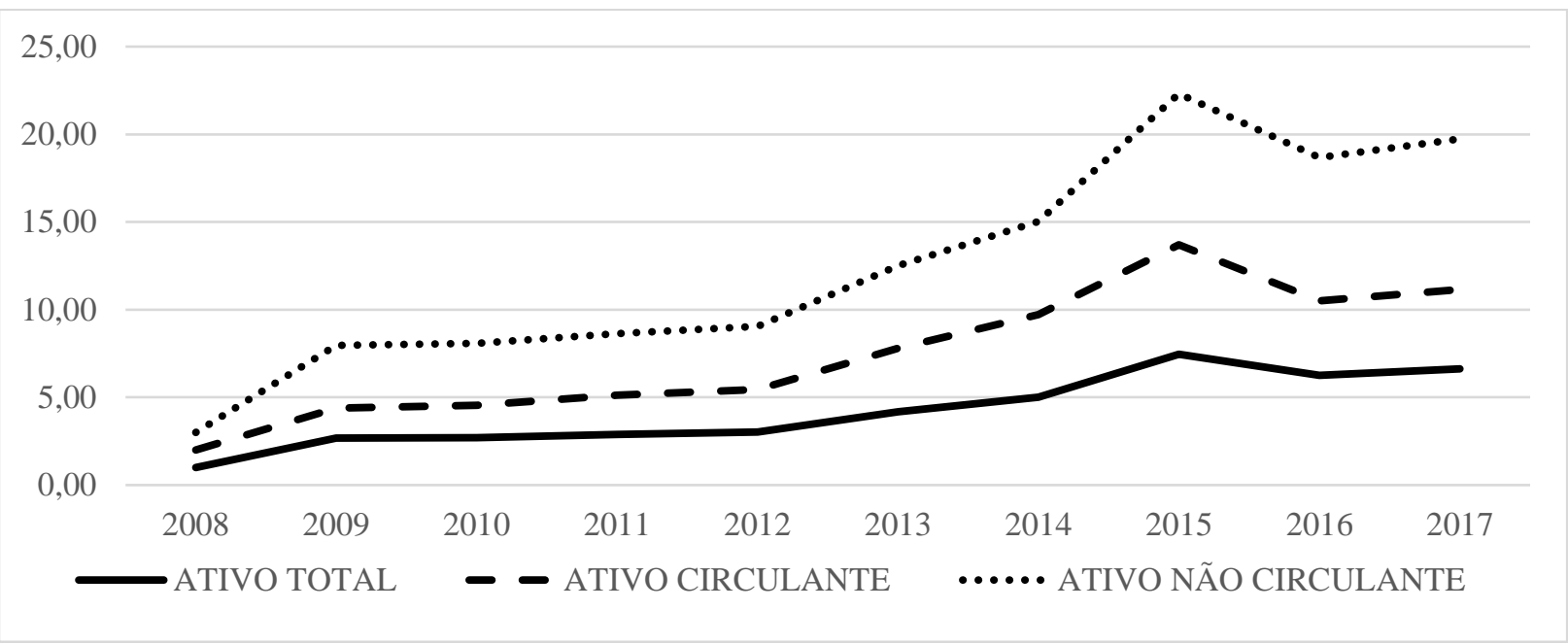

Fonte: Dados da pesquisa (2018).

No ano de 2009 o Ativo Não Circulante, se destaca com aumento de 257\% em relação ao ano de 2008, reflete a adição nas contas de Imobilizado e Intangível. Quanto ao Ativo Circulante, o acréscimo foi em torno de $72 \%$ em relação ao ano de 2008, reflexo das contas Caixa e Equivalentes de Caixa e Despesas Antecipadas. Do ano de 2009 a 2012 obteve aumento estável, onde em 2013 o Ativo Circulante cresceu 262\% em relação a 2008, resultado 
obtido por meio do aumento das contas Caixa e Equivalentes de Caixa, Contas a Receber e Ativos Biológicos, sendo o crescimento do Ativo Total em 318\% em relação ao ano base.

O maior aumento ocorreu no ano de 2015, quando o Ativo Circulante representou 624\% do período base, destacando-se Contas a Receber e a valorização dos Estoques no exterior. No Ativo não Circulante o aumento chegou a $761 \%$, provocado principalmente pelo crescimento de recebíveis de longo prazo e de Investimentos, retraindo as contas do Imobilizado e do Intangível. Em 2016, mesmo o Ativo Não Circulante mantendo um crescimento de $717 \%$, diminui em relação ao ano anterior, como consequência da diminuição das contas Caixa e Equivalentes de Caixa e Aplicações Financeiras. Por fim, no ano de 2017 houve um aumento das contas Aplicações Financeiras no Ativo Circulante e da conta de Ativo Realizável a Longo prazo no Ativo não Circulante.

Todos estes eventos podem ser explicados a partir da Figura 1, que apresenta a Linha do Tempo. As saídas de caixa e equivalentes de caixa, conferem com as aquisições e ampliação da empresa com a aquisição e compra de controle acionário de outras grandes empresas fora do país, o que aumentam as aplicações de longo prazo não circulantes. Mas, isto ainda não explica o aumento considerável do próprio Ativo Total, pois este foi significativamente aportado por recursos externos ou então lucros. Para esta dúvida, segue a análise horizontal do passivo total, representando as obrigações com terceiros e capital próprio.

Para demonstrar e avaliar a evolução dos elementos das contas do Grupo Passivo do balanço patrimonial da empresa JBS tendo como base o ano de 2008 analisa-se a Figura 2.

Figura 2: Balanço Patrimonial Passivo Período-base 2008

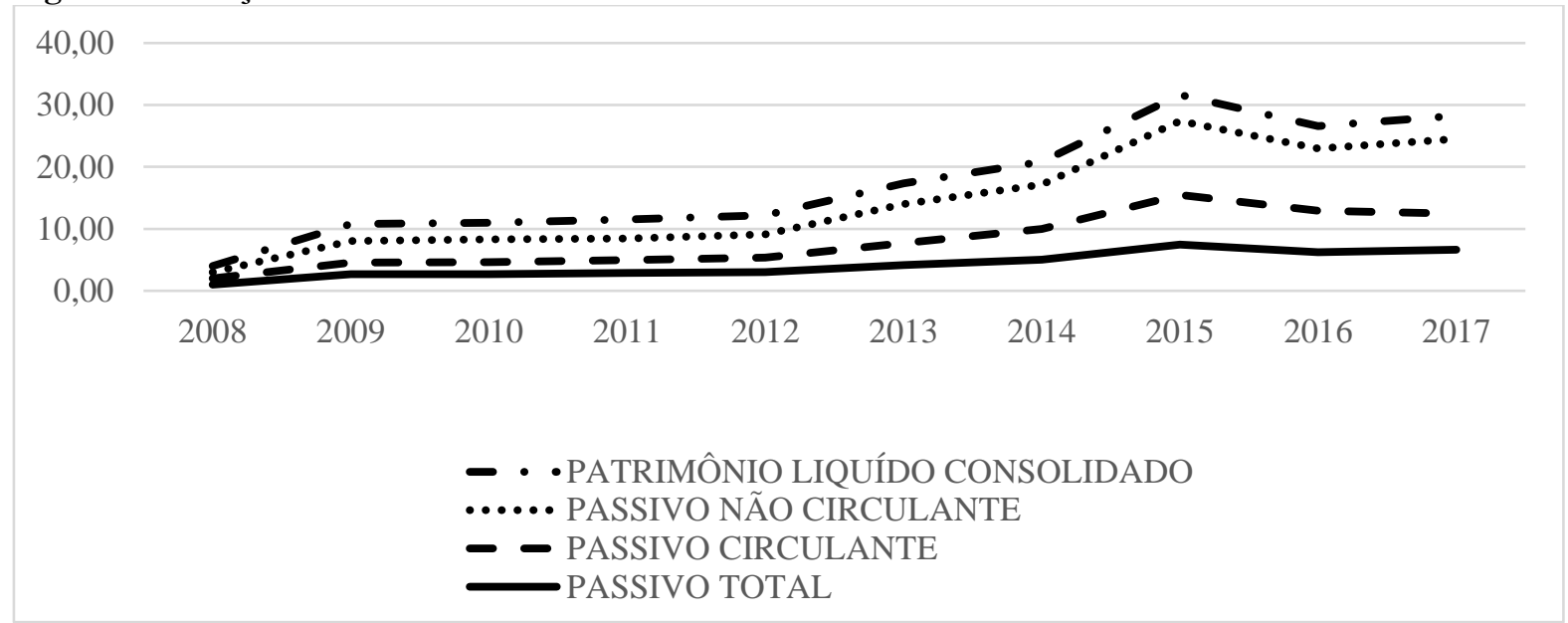

Fonte: Dados da pesquisa (2018).

$\mathrm{Na}$ análise da Figura 2, observa-se linhas crescentes do Passivo Total que possuem o mesmo comportamento ascendente do Ativo Total, conforme analisado na Figura 1. Porém, a estrutura da origem do capital, entre Circulante e não Circulante, assim como o Patrimônio Líquido Consolidado, oferece explicações interessantes, inclusive da origem de recursos que proporcionou o aumento das aplicações (Ativo). Mas, faz-se necessária a observação de quais grupos e subgrupos provocaram essas oscilações.

Primeiramente, o aumento de 2008 para 2009 e, diminuição imediata em 2010 no Patrimônio Líquido Consolidado, acompanhado do crescimento e declínio do Passivo Circulante e Passivo não Circulante, foi devido a Participação de Acionistas Não Controladores e Capital Social Realizado, ou seja, aporte de capital do mercado de valores. De 2010 até 2016, essa tendência de crescimento ocorre principalmente pelo aumento das obrigações de Empréstimos e Financiamentos e Obrigações Fiscais. A alteração dessa tendência de crescimento ocorre pela alteração de obrigações de longo prazo.

Para avaliar o Grupo de Contas das Demonstrações do Resultado do Exercício analisa-se a Figura 3 sendo o período-base o ano de 2008. 
Figura 3: DRE Período-Base Ano 2008

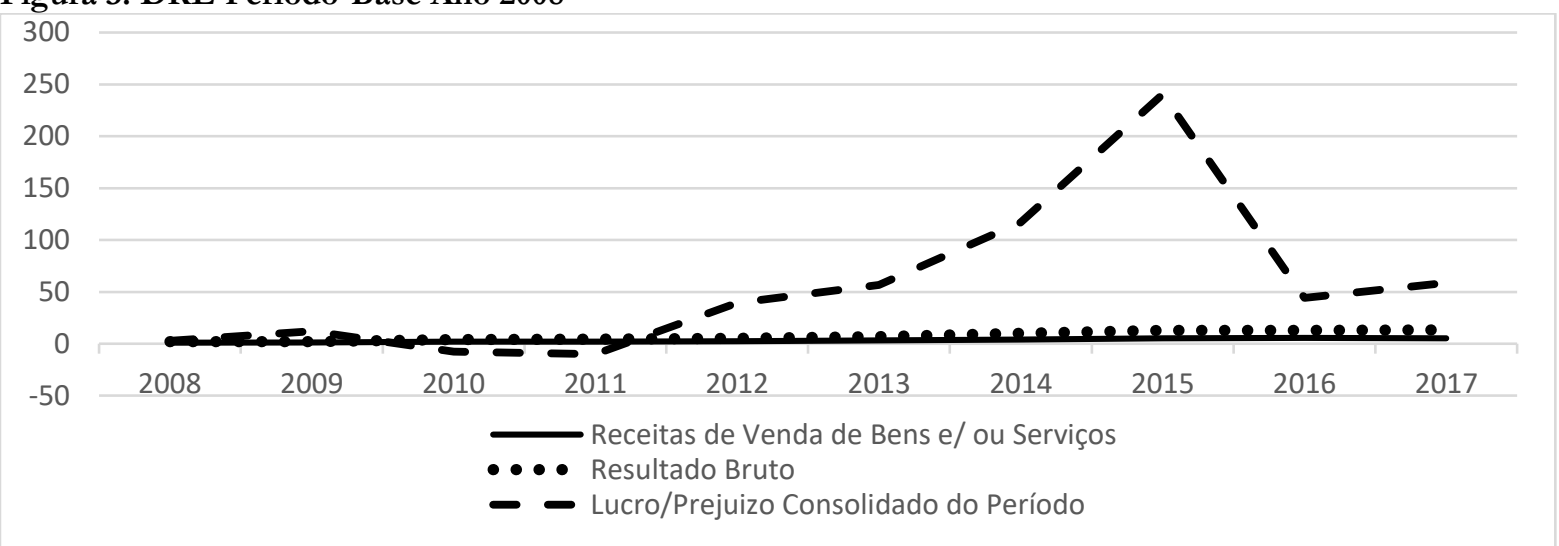

Fonte: Dados da pesquisa (2018).

A Receita com Vendas e Resultado Bruto possuem uma evolução linear e próxima, aumentando a partir de 2013 o Resultado Bruto, significando melhor eficiência na alocação dos custos de produção. Quanto a Lucro/Prejuízo Consolidado, o melhor resultado ocorreu em 2015.

\section{Análise Vertical}

A Análise Vertical diz respeito a composição dos grandes grupos do Balanço Patrimonial e da DRE. Pelo fato de haver um período mais longo, 2008 a 2017, é possível também, observar a tendência dessa composição. Inicialmente, a Figura 5 representa essa composição do Ativo da empresa JBS:

Figura 4 - Composição do Ativo no período de 2008 a 2017

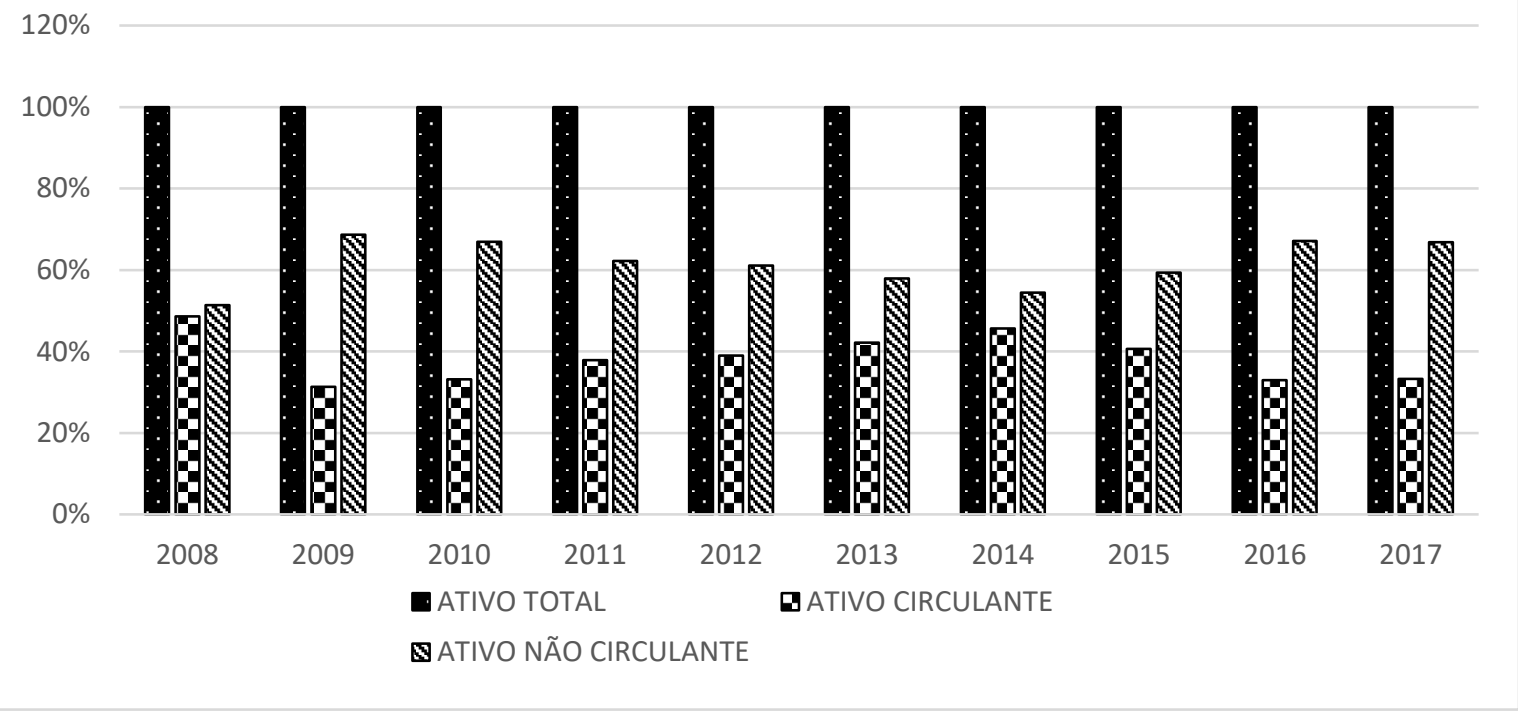

Fonte: Dados da pesquisa (2018).

Analisando a Figura 4, o Ativo Circulante apresenta valores relevantes em relação ao Ativo Total. Suas maiores participações foram no ano de 2008 com 49\% tendo como principal motivo a conta Estoque, em 2013 com 42\% e em 2014 com 46\%, tendo sua menor participação no ano de 2009 com 31\% resultado de diminuição de Conta A Receber e Aplicações Financeiras. Fechando 2017 com 33\% do Ativo Total. Nota-se uma diminuição da participação do Ativo Circulante/Ativo Total de 16\% em relação ao período inicial.

O Ativo Não Circulante em 2008 representou 51\% do Ativo Total, suas maiores participações ocorreram no ano de 2009 com 69\% tendo como principal motivo a conta Caixa e Equivalentes de Caixa, e em 2010, 2016 e 2017 com percentuais iguais a $67 \%$ em relação ao Ativo Total, ou seja, houve uma diminuição do período de 2009 a 2017, porém um aumento de $16 \%$ na participação do Ativo Total. 
Para demonstrar e avaliar a composição das contas do Grupo Passivo e Patrimônio Líquido da empresa JBS, segue a Figura 5:

Figura 5: Composição do Passivo Total da empresa JBS nos anos de 2008 a 2017

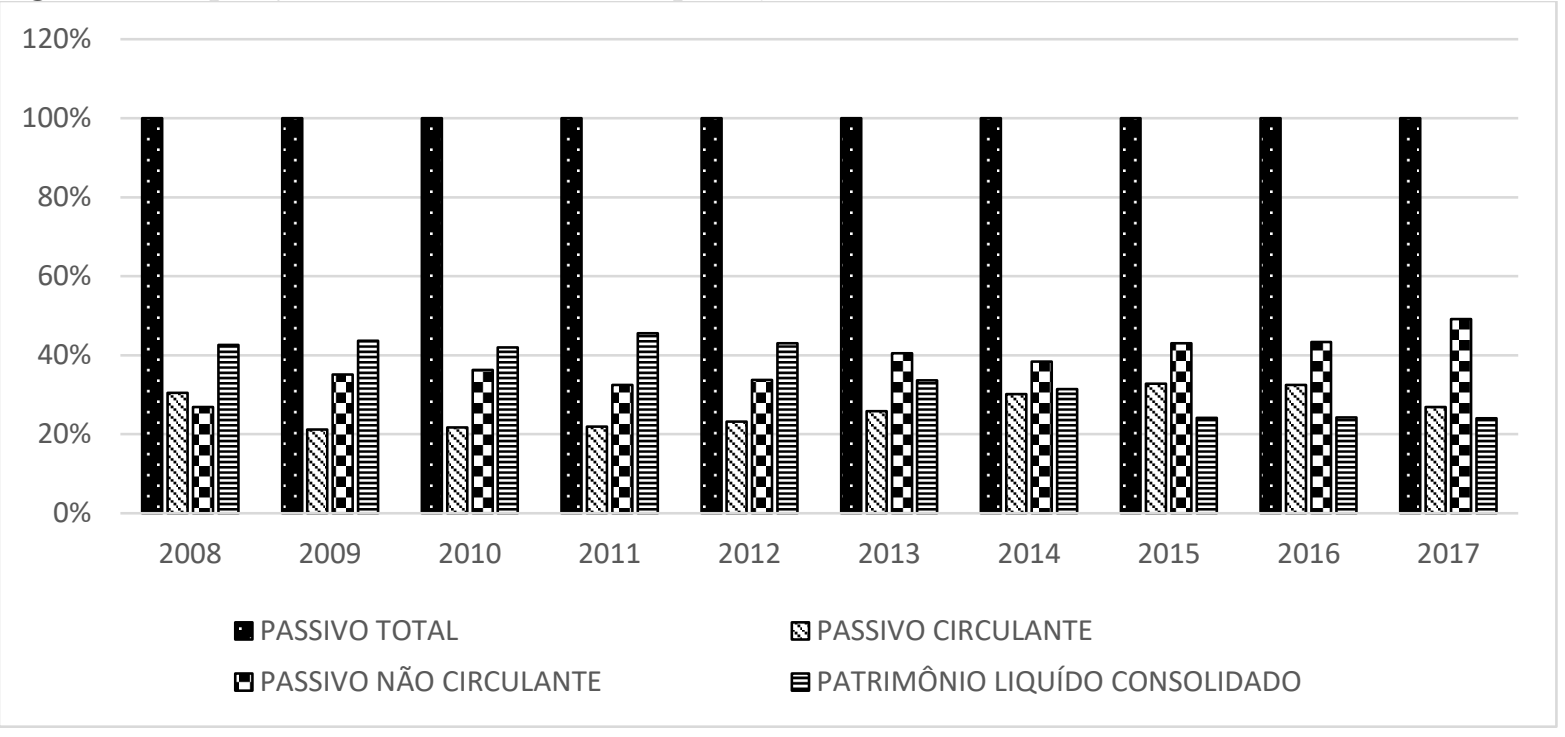

Fonte: Dados da pesquisa (2018).

Analisando o Passivo Circulante em 2008 inicia com 30\% de participação no Passivo Total, de 2009 a 2013 não passou de 26\%, em 2015 sobe para 33\% onde apresenta seu maior percentual de participação, caindo em 2017 para 27\% resultado da diminuição da conta Empréstimos e Financiamentos. Logo, seu declínio foi de 3\% em relação ao período inicial e de $6 \%$ em relação a 2015, resultado da conta Fornecedores e Empréstimos e Financiamentos. O Passivo não Circulante apresentou um avanço de $22 \%$ com relação ao período inicial da análise, começando em 2008 com 27\% e fechando 2017 com 49\% de participação do seu Passivo Total tendo como um dos motivos a conta Empréstimos e Financiamentos.

Por fim, o Patrimônio Líquido ao contrário do Passivo Não Circulante, obteve uma queda 19\% em relação a 2008 resultado da diminuição da conta de Reserva Total. Iniciou sua participação no Passivo Total com 43\%, chegou a 46\% no ano de 2011 e em 2015, 2016 e 2017 permaneceu com uma taxa de 24\% de participação no Passivo Total.

Para demonstrar e avaliar a evolução das contas da Demonstração do Resultado do Exercício analisa-se a Figura 6.

Figura 6: Análise Vertical da DRE do Período de 2008 a 2017

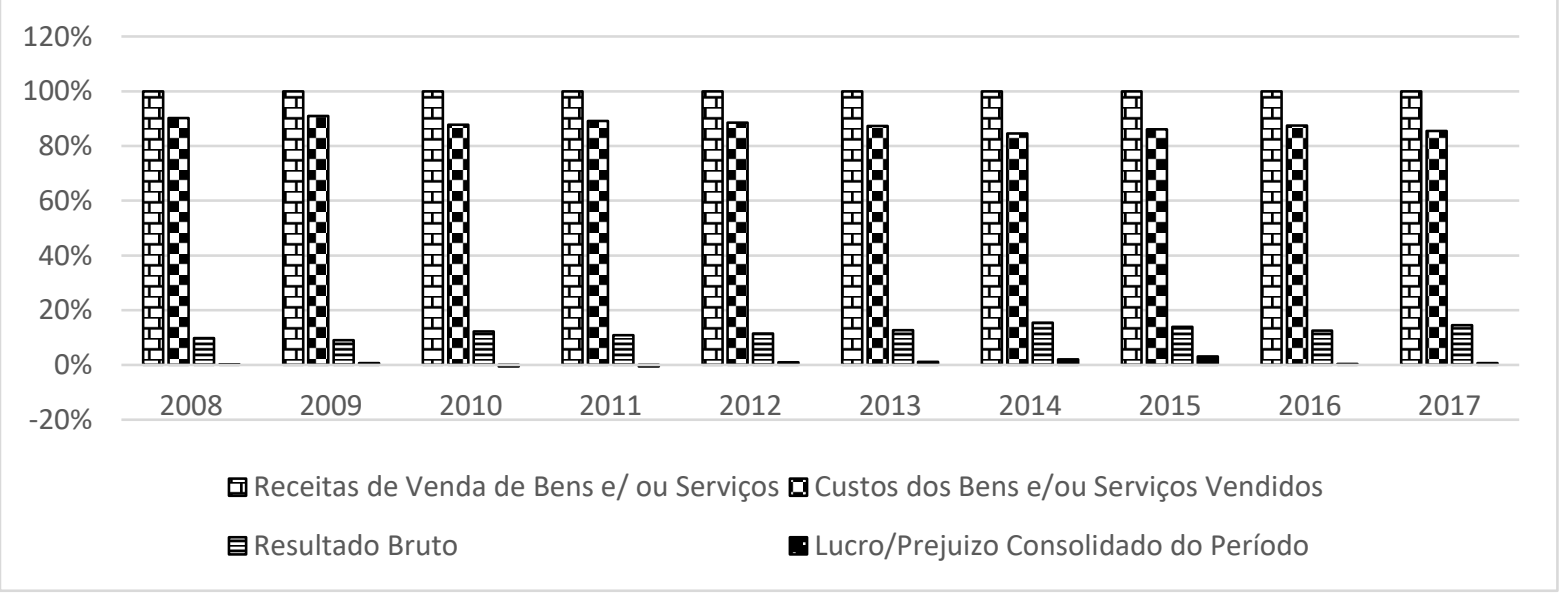

Fonte: Dados da pesquisa (2018). 
Com base na Figura 6 no ano de 2008 a conta de Custos dos Bens e/ou Serviços Vendidos tem participação de 90\% no valor da Receitas de Vendas, o Resultado Bruto participa com 10\% e o Lucro/Prejuízo Acumulado com $0,1 \%$.

Em 2009, os Custos dos Bens e/ou Serviços Vendidos possuem a maior participação no valor da Receitas de Vendas (91\%), o Resultado Bruto participa com 9\% e o Lucro/Prejuízo Acumulado com 0,6\%, um aumento com relação ao ano de 2008. No ano de 2010 Custos diminuem (88\%), porém, o maior Resultado Bruto (12\%) é absorvido por despesas, resultando em um Prejuízo Acumulado em relação ao ano de 2009.

No ano de 2011 Custos se mantêm em relação a Receitas de Vendas, mas não repercute em lucros, apresentando Prejuízo Acumulado. A partir do ano de 2012, a participação de Lucro Acumulado retorna, mantendo-se ascendente até o ano de 2016, chegando a 2,6\% do total da Receita. Para os anos de 2018 e 2017, embora essa representação diminua, os lucros se mantêm.

\section{Indicadores}

Nesta seção, são apresentados resultados e respectivos comentários pertinentes aos indicadores: Liquidez Corrente, Seca e Geral; Indicadores de Rentabilidade do Ativo e do Patrimônio Líquido; Indicadores de Endividamento; e, Indicadores de Prazos Médios.

A Figura 7 representa os dados relativos à Liquidez da empresa JBS, no período proposto (2008 a 2017), seguida de uma análise dos indicadores.

Figura 7: Indicadores de Liquidez Corrente, Liquidez Seca e Liquidez Geral

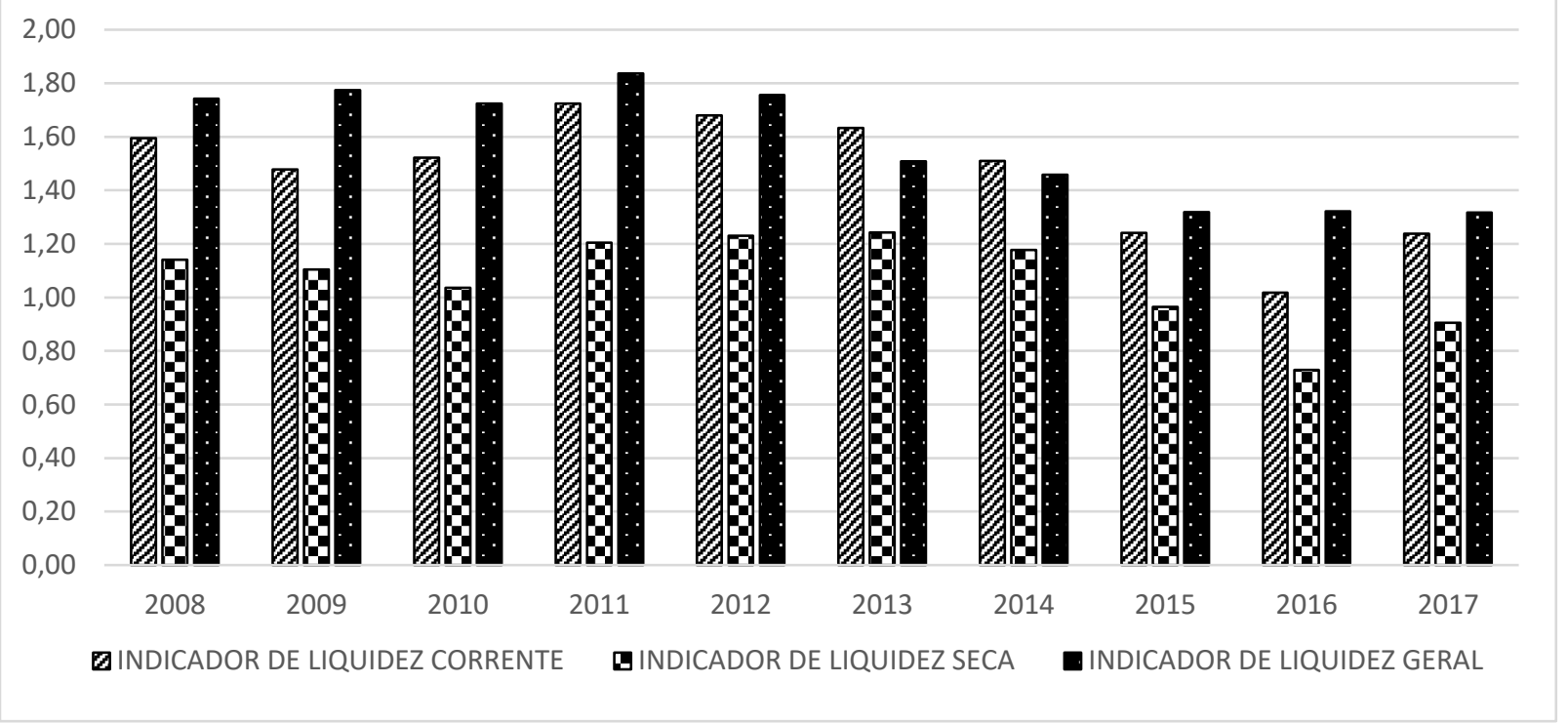

Fonte: Dados da Pesquisa (2018).

Em uma escala de 0 (zero) a 2 (dois), estão representados os indicadores que representam a capacidade de pagamento da empresa JBS. Primeiramente, o Indicador de Liquidez Corrente indica quanto a empresa possui de Ativo Circulante para cada $\mathrm{R} \$ 1,00$ de Passivo Circulante. Em todos os anos a empresa possui este indicador superior a 1 (um), portanto, os investimentos no ativo são suficientes para cobrir as dívidas de curto prazo e ainda permite uma folga financeira (59\% em 2008, 48\% em 2009, 52\% em 2010). Para o ano de 2011, essa margem de segurança alcança sua maior porcentagem $(72 \%)$, refletida provavelmente pelo de seus haveres em dólar. A partir de 2012 o índice inicia uma queda constante, chegando em 2015 com apenas 2\% (68\% em 2012, 63\% em 2013, $51 \%$ em 2014, 24\% em 2015, 2\% em 2016). Uma possível explicação para este fato seria a crise política instalada no país, o aumento dos custos de produção, perdas em operações financeiras e aumento de despesas com o pagamento de dívidas. Para o ano de 2017 , este índice já sobe para $24 \%$, ou seja, a empresa possuía para cada $\mathrm{R} \$$ 1,00 de dívida de curto prazo $\mathrm{R} \$ 1,24$ de bens circulantes. 
Em relação a Liquidez Seca, que considera o total do Ativo Circulante menos o Estoques, para os anos de 2008 a 2014, os valores em caixa e equivalentes de caixa são suficientes para cobrir suas dívidas de curto prazo, ou seja, mesmo se a empresa paralisasse suas entradas de caixa (vendas), por algum motivo, conseguiria saldar todos os seus compromissos de curto prazo permitindo-lhe ainda um índice de $24 \%$ de folga no ano de 2013 , sendo a maior durante o período analisado. Para os anos de 2015 a 2017, as margens ficaram abaixo de 1,00, o que significa uma incapacidade da empresa em quitar suas dívidas a curto prazo sem ter que vender seus estoques.

Por último, o Indicador de Liquidez Geral, que compreende Ativos de Passivos de curto e de longo prazo, estão todos acima de 1,00, representando que a empresa consegue pagar todas as suas dívidas de curto e de longo prazo, ainda se dispor de uma folga de 74\% em 2008, 77\% em 2009, 72\% em 2010, 84\% em 2011, 76\% em 2012. Essa margem diminui para 51\% em 2013, 46\% em 2014. Para os anos de 2015, 2016 e 2017, a margem se manteve constante $(32 \%)$. Cabe ressaltar que essa liquidez apresenta uma tendência de diminuição no período analisado, iniciando em 1,74 no ano de 2008 e para 2017, 1,32.

Próxima análise diz respeito a Rentabilidade do Ativo e do Patrimônio Líquido, que aponta para a rentabilidade dos investimentos da empresa e mede qual o lucro obtido sobre o investimento total aplicado (IUDÍCIBUS, 1998).

Figura 8: Indicadores de Rentabilidade do Ativo e Patrimônio Líquido

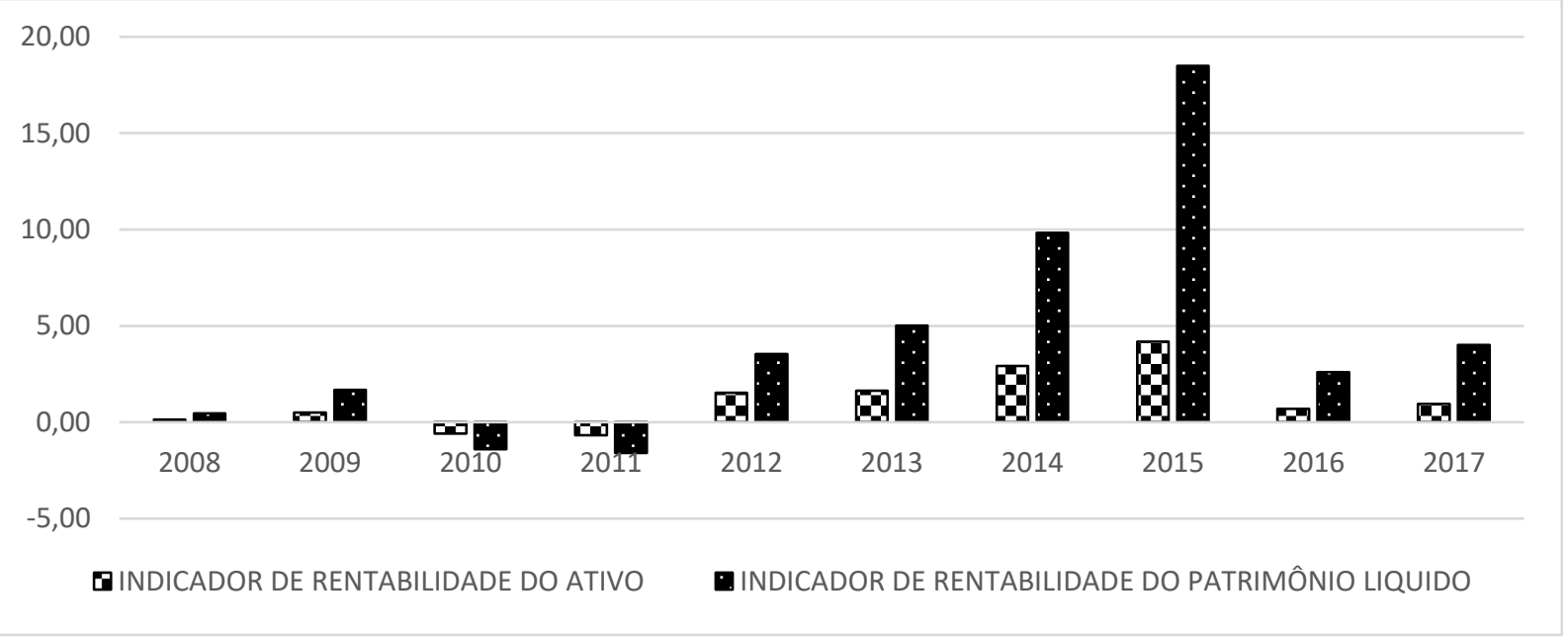

Fonte: Dados da pesquisa (2018).

A Figura 8, mostra que a empresa JBS no ano de 2008 obteve Rentabilidade do Ativo de 14\%, aumentando no ano de 2009 para 36\%. Em 2010 essa remuneração passou para valores negativos (-59\%). Em 2011 essa queda aumentou para (-68\%). Tendo por base o aumento das contas de Investimentos e Intangível. Ainda, reflexos da abertura de capital, em que houve grande incremento de capital externo, e respectivo valor de investimento para produção. Estes investimentos refletiram nos anos subsequentes, 2012, 2013 e 2014, sendo que o retorno aumentou para índices de 153\%,163\% e 292\% respectivamente, em 2015 obteve sua maior rentabilidade do ativo (419\%), ou seja, a cada $\mathrm{R} \$ 100$ de Ativo, a empresa obtinha um lucro de $419 \%$, o que significa que aumentou a capacidade da empresa em gerar lucro líquido e poder capitalizar-se. Em 2016 e 2017 os números foram de 69\% e $94 \%$ respectivamente.

O indicador de Rentabilidade do Patrimônio Líquido, representa o capital investido pelos sócios da empresa e quanto a empresa obteve de lucro para cada $\mathrm{R} \$ 100$ de Capital Próprio (MATARAZZO, 2003). Nota-se que em 2008 e 2009 para cada $\mathrm{R} \$ 100$ de capital próprio investido a empresa conseguiu 45\% e 168\% de lucro respectivamente. Em 2010 e 2011 esses números caíram para -140\% e -160\%. Nos anos de 2012 a 2015 esses indicadores aumentaram, 355\% em 2012, 502\% em 2013, 982\% em 2014 e 1.848\% em 2015, ou seja, aumentaram os números de investimentos próprio da empresa, aumentando assim os seus lucros. Nos anos de 2016 e 2017 as taxas foram de 259\% e 402\% respectivamente. Estes números são significativamente crescentes a partir de 2012, quando a empresa inverte sua estrutura de capital, passando a depender mais de Recursos de Terceiros, que mesmo assim, se transformaram em bons investimentos, remunerando de forma substancial o Capital Próprio. 
Indicadores de Endividamento possibilitam identifica qual o grau de capital investido de terceiros a curto prazo e qual o índice de capital próprio investido no Ativo Permanente (MATARAZZO, 2003). Essa evolução é apresentada na Figura 9.

Figura 9: Indicadores de Endividamento

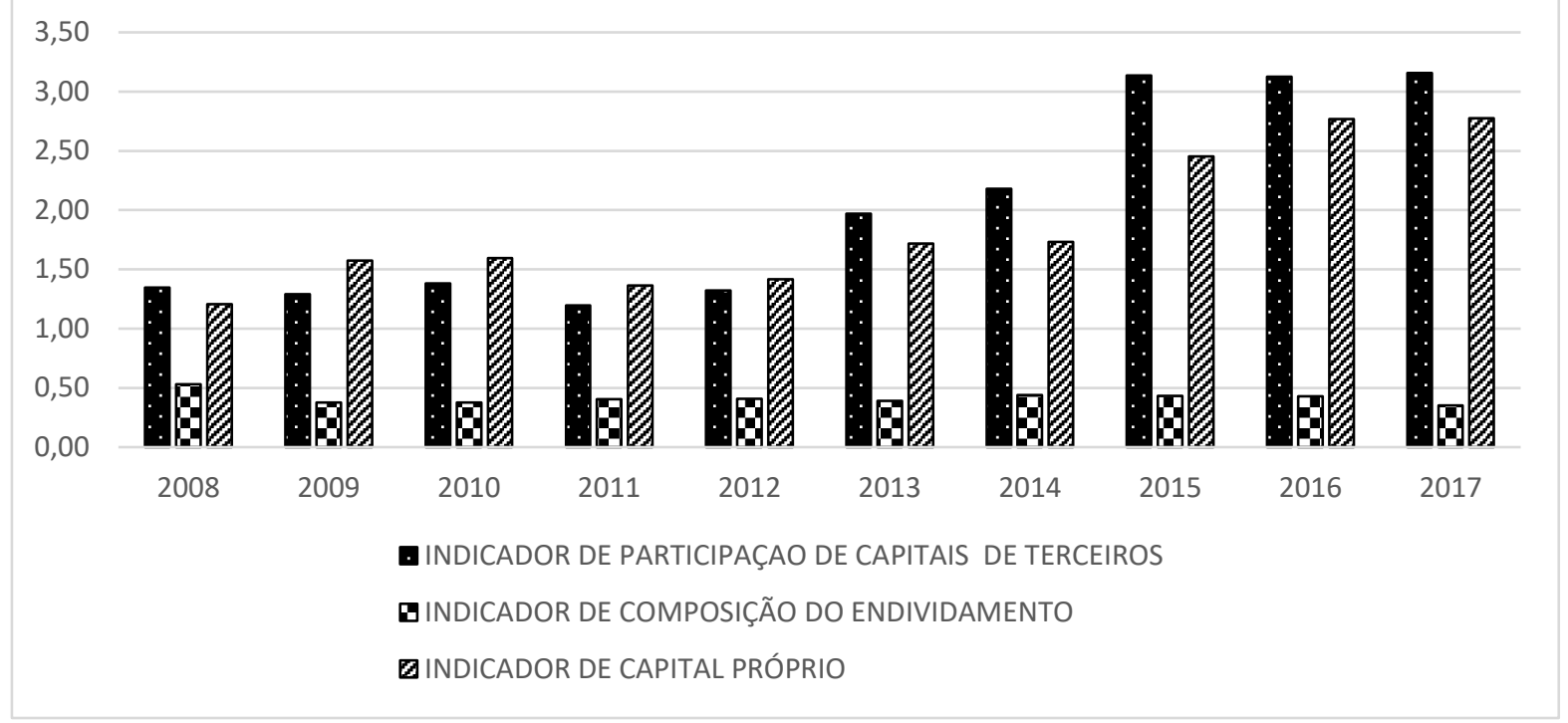

Fonte: Dados da Pesquisa (2018).

Para os exercícios analisados, a participação de capital de terceiros sobre recursos totais apresentou-se da seguinte forma: $135 \%$ em 2008, $129 \%$ em 2009, $138 \%$ em 2010, $120 \%$ em 2011, $132 \%$ em 2012, 197\% em 2013, $218 \%$ em 2014, 314\% em 2015, 313\% em 2016 e 316\% em 2017. Percebe-se que a proporção entre capitais de terceiros e patrimônio líquido utilizado pela empresa aumentaram durante o período analisado, o que significa um risco de dependência a terceiros por parte da empresa, pois quanto maior a relação de capitais de terceiros e patrimônio líquido, menor a liberdade de decisões financeiras da empresa

Após conhecer o grau de participação de capitais de terceiros, é importante saber qual a composição dessas dívidas. A Figura 8 indica que em 2008 a empresa JBS tinha 53\% de suas dividas vencíveis a curto prazo. Em relação a 2008, os outros anos em análise obtiveram uma porcentagem menor sendo 38\% em 2009, 37\% em 2010, 40\% em 2011 41\% em 2012, 39\% em 2013, 44\% em 2014, 43\% em 2015, 43\% em 2016 e 35\% em 2017, o que significa uma melhora do perfil de dívida da empresa. Lembrando que o endividamento não deve ser visto como algo negativo para a empresa, visto que é importante para seu crescimento.

Por fim na Figura 9, o Indicador de Capital Próprio mostra que em 2008 foram investidos no Ativo Permanente $121 \%$ do Patrimônio Líquido, sendo que quanto mais a empresa investir no Ativo Permanente, menos recursos próprios sobrarão para o Ativo Circulante. Em 2009 e 2010 os índices são praticamente iguais, sendo 157\% e 159\% respectivamente. Em 2011, 2012, 2013 e 2014 esses índices permanecem com máxima de 173\%, já em 2015, 2016 e 2017 os índices de investimentos do Ativo Permanente são de 245\%, 277\% e 278\% respectivamente. Neste sentido, observa-se que a participação de capital de terceiros é significativa no crescimento da empresa, sendo ele, o responsável pela expansão e consolidação da empresa em nível mundial.

Por fim, uma última análise foi feita para verificar a os prazos médios de vendas e pagamentos. Os Indicadores de Prazos Médios informam quanto tempo, em mé4dia, a empresa demora para receber suas vendas diárias, e pagar seus fornecedores. Também, avalia o tempo que o estoque leva para se transformar em produção vendida (MATARAZZO, 2003).

Representada na Figura 10, o recebimento de vendas da empresa JBS não ultrapassa a base de 35 dias, ou seja, manteve-se, em média, no período em análise com recebimento máximo de um pouco mais de 1 mês. Os prazos mais longos se deram no ano de 2009 (33 dias), e no ano de 2013 (34 dias). Os prazos mais curtos foram de 20 dias nos anos de 2016 e 2017. 
Figura 10: Indicadores de Prazos Médios

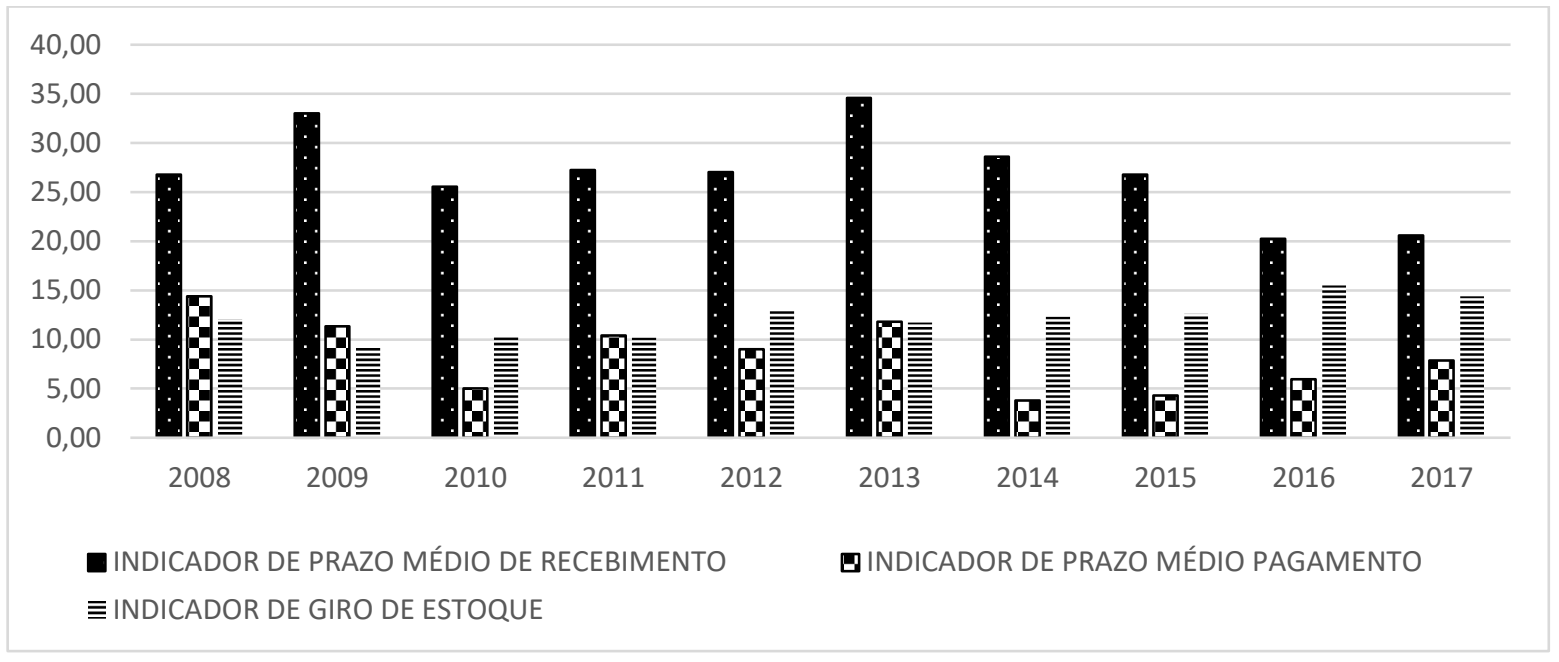

Fonte: Dados da Pesquisa (2018).

Para pagar seus fornecedores a JBS precisou de 14 dias em 2008, 11 dias em 2009, 5 dias em 2010, 10 dias em 2011, 9 dias em 2012, 12 dias em 2013, 4 dias em 2014, 4 dias em 2015, 6 dias em 2016 e 8 dias em 2017. Assim, os menores números de dias para pagamentos de fornecedores da JBS foram nos anos de 2010, 2014 e 2015 onde não ultrapassaram a faixa de 6 dias, em contrapartida os anos de 2008, 2009, 2011 e 2013 obtiveram um número superior a 10 dias. Fato que deve ser destacado aqui é que, os prazos para pagamento são superiores aos dos prazos de recebimento. Isso requer de uma empresa boa gestão de capital circulante, pois, suas saídas de caixa antecipam as entradas.

Por último, para a JBS vender seus produtos foram necessários 12 dias em 2008, 9 dias em 2009, 10 dias em 2010 e 2011, 13 dias em 2012, 12 dias em 2013, 12 dias em 2014, 13 dias em 2015, 15 dias em 2016 e 14 dias em 2017. A empresa apresentou seus melhores resultados no ano de 2009 onde precisou de 9 dias para que seus estoques se tornassem produção vendida, em contrapartida no ano de 2016 foi necessário um período maior, 15 dias.

\section{Considerações Finais}

O presente estudo teve como objetivo analisar as Demonstrações Contábeis Consolidadas do grupo José Batista Sobrinho - JBS, no Brasil, no período de 2008 até 2017, o presente estudo inicialmente procedeu com cálculos de Análises Horizontal e Vertical, seguida de cálculos dos Índices de Liquidez, de Rentabilidade, de Endividamento e de Prazos Médios. A pesquisa foi operacionalizada como estudo de caso e análise documental de forma exploratória e descritiva.

A Análise destaca que a empresa apresentou melhoria nos Demonstrativos Contábeis durante o período de estudo, com destaque para a (i) maximização dos indicadores de rentabilidade, (ii) indicadores de liquidez confortáveis, (iii) melhoria no perfil do endividamento da empresa, (iv) redução do prazo médio de recebimento das vendas e (v) aumento do giro do estoque. Em suma, fundamentos que destacam a melhoria da situação econômico-financeira da empresa.

No âmbito prático, o trabalho poderá auxiliar, principalmente, o processo de tomada de decisão de investidores e instituições financeiras, na comparação com diversas alternativas de investimento (e.g. concorrentes e outros setores). Por sua vez, no âmbito teórico, o trabalho complementa os trabalhos de Marcos et al. (2019) e Kronbauer (2013) e Assaf Neto (2012), especificamente, na importância da Análise das Demonstrações Contábeis para os usuários em geral. Em outras palavras, informações contábeis poderão ser utilizadas para sinalizar possíveis resultados futuros. 
A maximização dos indicadores de rentabilidade durante o período de análise é fundamental para busca de investidores. Os bons indicadores de liquidez foram fundamentais para continuidade da empresa. Já o aumento no giro do estoque, redução do prazo de recebimento de vendas e melhoria no perfil do endividamento são essenciais para uma boa gestão. Diante da importância da pesquisa, propõe-se para futuras pesquisas, a análise e discussão de como foram constituídos os aumentos e as diminuições dos valores das contas do Balanço Patrimonial e DRE que levaram ao resultado obtido durante esse estudo. De forma pormenorizada, avaliar a composição do Capital de Terceiros, vencimentos e prospecção de necessidade de caixa no futuro.

\section{Referências}

ASSAF NETO, Alexandre. Estrutura e Análise de Balanços: Um Enfoque econômico-financeiro. 10. ed. São Paulo: Atlas S.A., 2012.

BRAGA, Hugo Rocha. Demonstrações Contábeis: estrutura, análise e interpretação. 7. Ed. São Paulo: Atlas S.A., 2012.

BM\&FBOVESPA: A Nova Bolsa. Disponível em: <http://bvmf.bmfbovespa.com.br/cias-listadas/empresaslista-das/HistoricoFormularioReferencia.aspx? codigoCVM $=20575 \&$ tipo $=$ dfp\&ano $=2013 \&$ idioma $=p t-$ br>.Acesso em: 23 abr. 2018

CVM. Comissão de Valores Mobiliários. Consultas a informações de companhias. Disponível em: $<$ http://www.cvm.gov.br/menu/regulados/companhias/consultas/consulta-a-informacoes-decompanhias.html>. Acessado em 06 de maio de 2018.

ECONOINFO. Demonstrações do Balanço Patrimonial. 2017. Disponível em: $<$ http://www.econoinfo.com.br/financas-e-mercados/demonstracoes?codigoCVM=20575>. Acesso em: 04 dez. 2017.

EHRHARDT, Michael C.; BRIGHAM, Eugene F. Administração Financeira: Teoria e Prática. 2. ed. São Paulo: Cengage Learning, 2012.

EXAME. Melhores e Maiores: as 400 maiores empresas do agronegócio. Disponível em: $<$ https://exame.abril.com.br/revista-exame/400-maiores-do-agronegocio-3/>. Acesso em: 10/09/2019.

GERHARDT, Tatiana Engel; SILVEIRA, Denise Tolfo. Métodos de Pesquisa. 2009. Disponível em: <http://www.ufrgs.br/cursopgdr/downloadsSerie/derad005.pdf>. Acesso em: 06 dez. 2017.

IUDICIBUS, Sergio de. Analise de Balanços: analise da liquidez e do endividamento analise do giro e rentabilidade e alavancagem financeira. 7. ed. São Paulo: Atlas S.A., 1998.

JBS. História JBS. 2017. Disponível em: <http://jbs.com.br/sobre/historia/>. Acesso em: 07 dez. 2017.

J\&F. Linha do Tempo. Disponível em: < http://jinvest.com.br/quem-somos/linha-do-tempo/> Acesso em: 24 de janeiro de 2018.

KRONBAUER, Clóvis Antônio et al. Estrutura de capital de empresas do agronegócio: análise do endividamento geral e financeiro no período de 2004 a 2011. ABCustos, v. 8, n. 1, 2013.

KRUGER, Letícia Meurer. Análise da conformidade das demonstrações contábeis das fundações privadas de saúde do Estado de Santa Catarina. 2009. Disponível em: <https://repositorio.ufsc.br/handle/123456789/127004>. Acesso em: 22 nov. 2017.

MARCOS, Cleyson et al. Desempenho Econômico-Financeiro e o Grau de Internacionalização de Empresas Listadas no Novo Mercado da B3. Revista Contabilidade e Controladoria, v. 10, n. 2, 2019.

MARION, Jose Carlos. Analise das Demonstrações Contábeis: Contabilidade Empresarial. 7. ed. São Paulo: Atlas S.A., 2002.

MATARAZZO, Dante Carmine. Análise Financeira de Balanços: Abordagem básica e gerencial. 6. ed. São Paulo: Atlas, 2003.

QUEVEDO, Juliana Silva de. Análise das Demonstrações Contábeis da Sulmaq Industrial e Comercial SA. 2016.

Disponível

em:

ISSN 2318-9231

CGE | Rio de Janeiro | v. 8 | n. 2 | mai.-ago. 2020 
<https://www.univates.br/bdu/bitstream/10737/1498/1/2016JulianaSilvadeQuevedo.pdf>. Acesso em: 04 dez. 2017.

RAUPP, Fabiano Maury.; BEUREN, Ilse.Maria. Metodologia da pesquisa aplicável às ciências sociais. In. BEUREN, I.M. (Org.). Como elaborar trabalhos monográficos em contabilidade: teoria e prática. 3.ed. São Paulo: Atlas, 2006. Cap.3, p.76-97.

ROSS, Stephen A.; WESTERFIELD, Randolph W.; JORDAN, Bradford D. Administração Financeira. 8. ed. São Paulo: Amgh Editora Ltda, 2008.

VALOR ECONÔMICO. Valor 1000. As 1000 maiores empresas do Brasil. Disponível em: $<$ https://valor.globo.com/empresas/>. Acesso em 10/09/2019.

VAZ, Tatiana. Além da JBS, de quem mais a J\&F é dona? 2017. Disponível em: $<$ https://exame.abril.com.br/negocios/alem-do-banco-original-de-quem-mais-a-j-f-e-dona/>. Acesso em: 05 fev. 2018.

VIANA, Júlio. Quem é a JBS: saiba quais são as marcas que fazem parte do grupo. Disponível em: < http://revistagalileu.globo.com/Sociedade/noticia/2017/05/quem-e-jbs-saiba-quais-sao-marcas-que-fazemparte-do-grupo.html>. Acesso em: 19/10/2017.

YIN, Robert K. Estudo de caso: planejamento e métodos. São Paulo: Bookman, 2005. 